\title{
Hermeneutics Studies On Representation Of Merry Riana On Her Biography Cover Design
}

\author{
Asthararianty ${ }^{1}$, Fanny Lesmana ${ }^{2}$ \\ ${ }^{1}$ Visual Communication Design Department, Petra Christian University, Surabaya; Indonesia \\ ${ }^{2}$ Communication Science Department, Petra Christian University, Surabaya; Indonesia
}

astha@petra.ac.id,flesmana@petra.ac.id

\begin{abstract}
The development of book, both on cover or content, has been changed depending on the trend of design at that time. Nowadays, among many various books, biography is a kind of book that attracts readers. Biographies are becoming more frequently published, both written by writer and the figures themselves. Most of the covers of the biography always show the figure in the form of photos or similar pictures of oneself in one distinctiveness of each character. Merry Riana was the figure of female motivator whose biography had been published. These two biographies also described the life journey of Merry Riana in achieving success in her life. This study wanted to see how the figure of Merry Riana as a female motivator was represented in the cover design of her biography, which is the subject of the study is the cover design of the books entitled Mimpi Sejuta Dolar and Langkah Sejuta Suluh. This study used qualitative method with the approach of Gadamer's hermeneutics. The results of this study were to show that a female motivator, Merry Riana, who was illustrated in the cover design of the book, was a woman who was brave and determined to reach the peak of success.
\end{abstract}

Keywords: book, cover design, motivator, woman

\section{Introduction}

"Don't judge the book by its cover", is common proverb which people often hear. Front cover of a book is frequently going to affect reader's desire to buy a book. It is one of the essential parts in designing book to consider. Lee (2004) stated that the process in composing book starts from the author's idea which then delivers to the designer to illustrate the idea into cover design or layout.

The development of book, both the cover and content, has undergone changes depending on the trends of book design at particular time. Currently, biography is a book genre which attracts readers' attention. Suwarno (2014), stated that biography is re-disclosure of personal life given from memory, either from written or spoken form.

The one and only Indonesian motivator whose biography has been published was Merry Riana. A book entitled Mimpi Sejuta Dollar was written by Albertine Endah (2011) and Langkah Sejuta Suluh was written by Clara Ng (2014). These two biographies described Merry Riana life journey to reach her success in life.

A person is called as motivator since she/he is able to encourage and inspire the people, so does Merry Riana. She gives motivation to the people. Therefore, the people or the audiences also expected a better life as she told to them. Does a motivator face hard-time in his life? How does s/he overcome the problem?

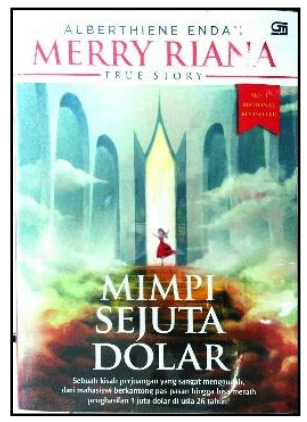

Figure 1 Mimpi Sejuta Dolar Book Cover 


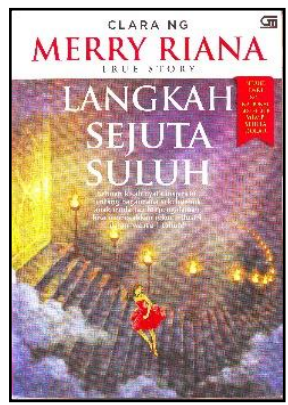

Figure 2 Langkah Sejuta Suluh Book Cover

Albertine Endah and Clara Ng, both are the professional writers who have different writing style and genre. Albertine Endah is known as biography writer. Meanwhile, Clara Ng is renowned novelist. The difference of genre of both writers is interesting to be analyzed in visualizing Merry Riana.

The study focused on biographies as the subject was not much done and found. One of them was research done by Marsinta Dewi conducted in 2013. However, the research conducted by Marsinta Dewi concerned on implementation of a method carried out by High School students in reading biographies using quasi experimental method. Meanwhile, the current study was focused on the cover design of biographies as the subject of the research through text analysis research method, hermeneutics method.

\section{References}

The method used in this study is hermeneutic which is initiated by Gadamer. Schleiermacher in Rahardjo (2008: 40) stated that hermeneutic is understanding the text better than the author's understanding. This can be done through two ways; those are by mastering the language grammar and styles of the writer and by catching the emotion by interpreting writer's schemata.

Nonetheless, according to Pilliang in Walker (2010: 101), hermeneutic is the process of interpreting the possibility of an object. The interpretation is opened, contextual, and relative which may not have absolute truth.

\section{Result and Discussion}

The researchers interpreted and discussed the design of Merry Riana book cover based on the elements of design by Lee, as follows:

\section{Subject}

The content of the book must be represented by the book design; especially for aspects related to the subject. At some important points of the subject later will package the book more interesting through the design and uniqueness. Lee (2004:410) stated that the subject of the book content can be illustrated either completely complicated or simply usual template.

Cover of Merry Riana biography was the cover which expressed several aspects of Merry Riana life. Those aspects could be shown as follows: i. Book Titles

a. Book 1: Mimpi Sejuta Dollar (MSD) by Alberthiene Endah

b. Book 2: Langkah Sejuta Suluh (LSS) by Clara $\mathrm{Ng}$

(source: private documentations)

ii. Brief description or blurb
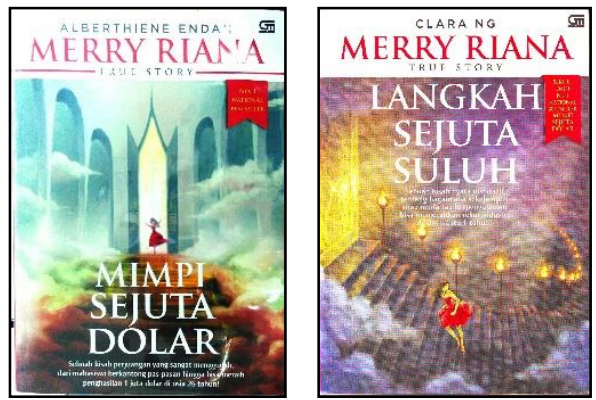

Figure 3 comparation of the two books

a. Book 1 - Mimpi Sejuta Dollar (MSD): an evocative struggling story of middle-class female university student who earned money up to one million dollars at the age of 26 years.

b. Book 2 - Langkah Sejuta Suluh (LSS): an inspiring true-life story about how some inexperienced youngsters reach industrial record for just in a year.

(source: private documentations)



Figure 4 Brief description

iii. Tagline : using True Story tagline in both books, MSD and LSS books.

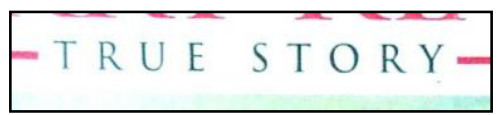

Figure 5 Tagline (source: private documentations)

iv. Character name: Merry Riana

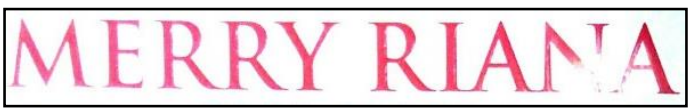

Figure 6 Character name

(source: private documentations)

v. Testimonial : the status of biography

a. Book 1-MSD: No. 1 National Bestseller 
b. Book 2 - LSS: Sequel to No.1 National Bestseller, Mimpi Sejuta Dollar
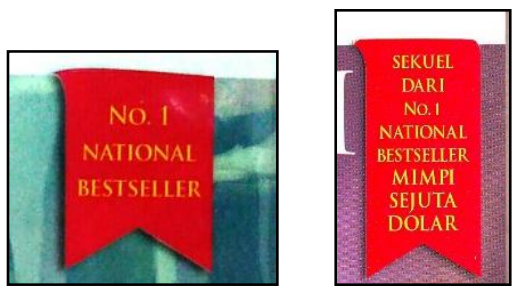

Figure 7 the status of biography

(source: private documentations)

On the description above, the subject who becomes the source of this biography is Merry Riana. This character is repeatedly described through Merry Riana's life who is a middle-class university student. The name of the character "Merry Riana" is shown in big size on the top of book cover, while the short description of Merry Riana is from the blurb which is supported by True story tagline. This Merry Riana biography is also definitely phenomenal due to its first position as National Bestseller. Lee states that the subject could be described simply or complicatedly. In this biography, the subject is shown very explicitly regarding the repetition and the place of the character's name and its big size. It is not only explicit but also simple thus the readers directly know and understand the subject of this book.

\section{Illustration}

The illustrations used could be taken from inside the book or other sources that are still in accordance with the subject of the book's contents. These illustrations should be able to make the cover design and content to be integrated (unity).

The cover of Merry Riana biography used illustration which is able to display the contents of the book. There are several differences between books, book 1 - MSD and book 2 - LSS.

i. $\quad$ Book 1 - Mimpi Sejuta Dollar (MSD) by Alberthiene Endah

(source: private documentations)

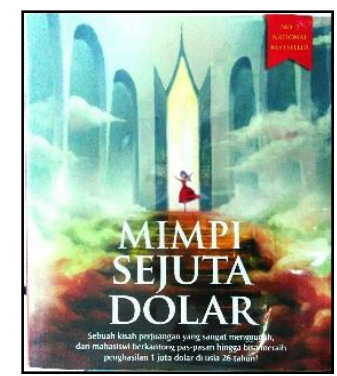

Figure 8 Book 1 - Mimpi Sejuta Dollar (MSD) by

Alberthiene Endah
Illustrations which are shown in book 1 - MSD are as follows:

a. The picture of woman in red stretched her arms onward at the top of the stairs

b. The picture of the stairs which was narrowed upward.

c. The picture of an open door which had lighter color than the windows.

d. The picture of vague clouds.

Picture "a" showed a woman. The woman is definitely described as a character in this biography, she is Merry Riana. This woman is illustrated wearing red dress. Several photos which are exposed in cyberspace showed that Merry Riana mostly worn matching dress like gown.

Stretching the arms out generally depicted that people feel happy with various reasons. One of the reasons could be feeling relieved after being successful for doing something or winning something. In this case, this picture of the woman is in accordance with the blurb on the front cover which said "bisa meraih" (can reach).

Front cover depicted this woman is at the top of the stairs. Top is the upper or highest place. The top of the stairs interpreted the highest part of the stairs. Top was also likened to success, like the peak of one's success. The woman who is at the top of the stairs could be said to have reached or achieved her success, the most successful.

Picture " $b$ " is the picture of conical narrowing upward stairs. This picture could be interpreted as picture "a", which is the highest place of the woman at the stairs. The conical top of the stairs was linked with the peak or the highest point, the most successful. These stairs were interpreted as the steps which led to the highest peak, the peak of success.

Picture "c" is the picture of an open door with the brighter color than the windows. This door was behind the woman in red. This door was a place where the woman wanted to go to. But, the woman was still outside the door, precisely in the front of the bright-color door. This door was the highest threshold of success. The shape of the door and the windows was towering and large. The book described that the character was a very spiritual figure and close to God. This large door and windows could be interpreted as God Almighty and the kingdom of His heaven.

Picture " $\mathrm{d}$ " is the vague clouds. This picture was connected with picture "c", it depicted the illustration of the kingdom of God in which these vague clouds was as the support to the kingdom of heaven.

The pictures as illustrations on this biography cover wanted to show the unity of the story told in the book. Starting from a figure who succeed passing the lower stairs to the top of the stair, her steps finally got her to be a very spiritual one. That figure was a woman namely Merry Riana. 


\section{Typografy}

ii. $\quad$ Book 2 - Langkah Sejuta Suluh (LSS) by Clara Ng

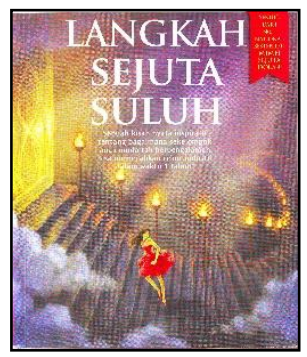

Figure 9 Book 2 - Langkah Sejuta Suluh (LSS) by Clara Ng

(source: private documentations)

The pictures shown on book 2 - as follows:

a. Picture of woman in red stepping up on stairs and looking back

b. Narrower conical stairs to the wider ones.

c. There is torch light seen from the smaller that almost unseen to the biggest seen in sequence.

d. The Clouds.

e. The Golden door.

f. The Sunlight like effect.

Picture "a", it was like the MSD book telling a woman, a figure wearing bright red dress. Her position seemed she runs to step the stairs while looking back. Her position was different from the previous book of which purposely showed by the title which depicted the steps that should be climbed to reach the door.

Picture "b" is the picture of the conical stairs which got narrower contrarily with the previous book (MSD). In LSS book, the conical stairs got wider from the narrow ones. It showed that the author wanted to expose the abundant of process and lots of stairs had been stepped (Merry Riana as the main character).

Picture "c", the torchlight, was an illustration and the description of the title "Langkah Sejuta Suluh" (Step of Thousand Torchlights). The picture wanted to show clearly that there was a strong belief of the main figure that wanted to be exposed clearly.

Pictures " $d$ ", "e", and "f" were the pictures which were interrelated unto God and Merry Riana's faith that every single story she was going through based on God path ways. This was also shown on MSD book.

Those two book covers showed that there were differences of both of the position of the woman who was the main character and the position of the stairs. In addition, there were the torches along the stairs, the position of reversed conical stairs and the effect of sunlight. The contents of those two books told every single story that the author really wanted to base on the blurb aforementioned on the previous part.
Choosing typography is also the requirement or essential point from the cover appearance to be seen as the whole (unity). The need to be showed on book cover corresponds with the content, whether the contents need special fonts, size, and thickness and others.

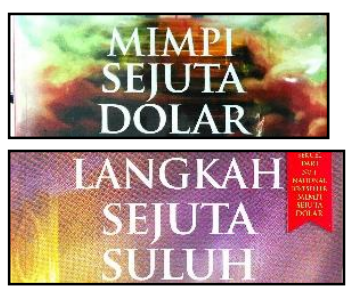

Figure 10 . Typografy

(source: private documentation)

The choice of font face of both MSD and LSS book was Serif type. The characteristic can be seen from the Serif font, which is according to the theory, there is a combination of stem and stroke curving out till showing the coming out lines. The theory tells that this font is used to impress the toughness, seriousness, and formality.

In MSD and LSS book, they used the same font face. The author wanted to tell that the stories in those books were serious and formal.

\section{Material}

Lee (2004:411) states that the use of paper for book cover chosen separately with the basic technique and the budget estimation as well. In this part, the material would not be explained within the details.

\section{Colors}

The use of colors on certain book cover wholly based on the book design or what design be like. Color should be correlated with the book content. Colors which were used should be able to depict more expression and attention.

Colors used in MSD and LSS book were dominated by dark intensity color and some colors which had been the center of attraction and described the book content or message that the author wanted to tell. Those colors were as follows:

a. Mimpi Sejuta Dollar (MSD) or Million Dollars Dream book had dominantly blue and dark red in colors. The blue color was in the illustration of the towering doors mixed with white color which was in relation to greatness impression. The bright blue depicted on clouds. The blue color itself brings the impression of greatness and gorgeous. Meanwhile, the dark red was in clouds and in the conical upward stairs as well. Then, the stunning color of MSD book front cover was red, the color of dress worn by the woman. The red color was also used in flag and book title. Red usually indicates the bravery, warmness. This color also enables to be center 
of attention or striking color in comparison with other colors, blue and dark red.

b. Langkah Sejuta Suluh (LSS) or Step of Thousand Torchlight had dominant colors which were visibly different from MSD book. The colors of LSS were dominated by purple and yellow. The LSS book which was dominated by purple color balanced with the color of torchlights. There were several intensities of purple color in this book cover, in its background and the stairs as well. The golden color is also used for the door. The harmony of color was described on the mixture of white and purple in the clouds. The impression of purple color is great, and purity. Meanwhile the gold brings the impression of greatness, luxuriousness, and brightness.

\section{Conclusion}

This purpose of the study was to know how the representation of Merry Riana, as a female motivator, from her biography. Meanwhile the representations which were seen from the book cover design, as follows:

1. These biography books could be told from the cover, a brave woman, passionate, and strugglepowering woman (with the red color of her gown, and it was repeated on MSD and LSS book). Besides, the figure of woman in the cover was also shown as a feminist woman with her long hair wore gown.

2. Describing Merry Riana who always believes in God all her life with the great illustration of the big and tall castle window and golden door.

3. The cover depicted the toughness of her life by taking long stairs to reach the top as an analogy. Then it is placed lower than the woman in the book cover.

4. The colors shown on the cover showed the contrasted colors. About darkness and brightness.

From above-mentioned points, it could be said that Merry Riana is also a female motivator in Indonesia. However, her character as a motivator is not very visible in the cover design. The character which was illustrated in the book cover design was just a picture that shows Merry Riana was a brave and passionate woman (it was illustrated perfectly on red gown) who underwent toughness of life and she has stepped on the top stair and also possess strong faith (illustrated with clouds and great window and golden door)

\section{REFERENCES}

A. Books

Moleong, Lexy. 2012. Metodologi Penelitian Kualitatif edisi Revisi. Bandung: Remaja Rosdakarya

Noor, Juliansyah. 2011. Metodologi Penelitian. Jakarta: Kencana

Raharjo, Mudjia. 2008. Dasar-Dasar Hermenutika, Antara Intensionalisme \& Gadamerian. Jogjakarta : Ar-ruzz Media.
Riswandi. 2013. Psikologi Komunikasi. Yogyakarta: Graha Ilmu

Sobur, Alex. 2009. Semiotika Komunikasi. Bandung: Remaja Rosdakarya

Sumaryono, E. 1999. Hermenutik, Sebuah Metode Filsafat. Jogjakarta: Kanisius.

Suwarno, Wiji. 2014. Perpustakaan dan Buku: Wacana Penulisan dan Penerbitan. Jogjakarta: Ar-ruzz Media

Vivian, John. (2008) : Teori Komunikasi Massa. Edisi ke-8. Jakarta: Kencana.

Walker. A. John. 2010. Desain, Sejarah, Budaya, Sebuah Pengantar Komprehensif. Jogjakarta: Jalasutra.

B. Journals

Dewi, Alit Kumala. Semiotika, bagian I. Diakses dari http://repo.isi-dps.ac.id/464/1/469-1617-1-PB.pdf, pada 27 November 2016

Dewi, Marsinta. 2013. Penerapan Metode Jigsaw II Dalam Pembelajaran Membaca Teks Biografi (Penelitian Eksperimen Semu pada Siswa Kelas XI SMA Pasundan 2 Bandung Tahun Ajaran 2012/2013). Jakarta: Universitas Pendidikan Indonesia. Diakses dari http://repository.upi.edu/2085/4/S_IND_0907458_Cha pter1.pdf, pada 27 November 2016

Hidayat, Marifka Wahyu. 2014. Analisis Semiotika Foto pada Buku Jakarta Estetika Banal karya Erik Prasetya. Diakses dari http://repository.uinjkt.ac.id/dspace/bitstream/1234567 89/27362/1/MARIFKA\%20WAHYU\%20HIDAYATFDK.pdf, pada 27 November 2016 